\title{
Inglise keele kui võõrkeele õppijate õpistrateegiad ja nende mõju õpitulemustele
}

\author{
Katrin Saks ${ }^{\mathrm{a} 1}$, Äli Leijen ${ }^{\mathrm{a}}$, Karin Täht ${ }^{\mathrm{b}}$ \\ ${ }^{a}$ Tartu Ülikooli haridusteaduste instituut \\ ${ }^{b}$ Tartu Ülikooli psühholoogia instituut
}

\begin{abstract}
Annotatsioon
Võõrkeeleoskuse omandamist on võimalik toetada, arendades õppijate keeleõppestrateegiaid. Õpistrateegiate uurijad on töötanud välja erinevaid õpistrateegiate taksonoomiaid, kuid tõendid nende valiidsuse kohta on vastukäivad. Selle uurimuse eesmärk on leida empiirilistele andmetele kõige paremini vastav keeleõppestrateegiate klassifikatsioon ning uurida keeleõppestrateegiate seoseid ja nende mõju õpitulemustele. Kinnitava faktoranalüüsi tulemused näitavad, et modifitseeritud ja täpsustatud kuuefaktorilisel mudelil on head mudeli headuse indeksid. Eestikeelses Est-SILLi mudelis moodustus kuus strateegiarühma: metakognitsioon, sotsiaalsed, kompensatsiooni- ja mälustrateegiad ning aktiivne keelekasutus ja seostamisstrateegiad. Struktuurivõrrandite mudelite analüüsiga saadud tulemused kinnitavad, et kognitiivsed õpistrateegiad avaldavad õpitulemustele otsest mõju, kuid metakognitiivsed õpistrateegiad mõjutavad õpiedu kaudselt, kognitiivsete strateegiate kaudu.
\end{abstract}

Võtmesõnad: keeleõppestrateegiad, struktuurivõrrandite mudelid, kinnitav faktoranalüüs

\section{Sissejuhatus}

Õpistrateegiad on tegevused ja võtted, mida õppijad kasutavad informatsiooni paremaks mõistmiseks, meenutamiseks ja rakendamiseks (Oxford, 1990). Need tegevused on vajalikud aktiivseks, teadlikuks, eesmärgipäraseks ja keskendunud õppimiseks. Õpistrateegiate seotus õpitulemustega annab võimaluse hinnata strateegiate kasutuse edukust (Hsiao \& Oxford, 2002; O’Malley \& Chamot, 2002; Rubin, 1975). Õppija strateegiline

1 Haridusteaduste instituut, Tartu Ülikool, Salme 1a, 50103 Tartu; katrin.saks@ut.ee 
käitumine ja õpistrateegiate valik on põhjuslikus seoses tema keele omandamise ja kasutamise edukusega (Purpura, 1998). Edukat keeleõppijat iseloomustab õpistrateegiate oskuslik valik ja tõhus kasutamine, sügav õpihoiak ja oskus struktureerida oma teadmisi, sealhulgas keeleõppega seotud teadmisi (ibid.). Nagu varasemad uuringud (Kauffman, Zhao, \& Yang et al., 2011; Kramarski \& Michalsky, 2010; Saks \& Leijen, 2015) on näidanud, paranevad õppijate õpitulemused võõrkeelekursusel kognitiivsete ja metakognitiivsete õpistrateegiate kasutuse kaudu. Õpistrateegiate oskuslik kasutamine muudab õpiprotsessi tulemuslikumaks, toetab õppija õpiautonoomia arengut ja enesejuhtimisoskust (Wong, 2011).

Selle artikli aluseks olev uuring tehti Eesti abiturientide hulgas. Inglise keelt võõrkeelena on Eesti koolides õpetatud 1930. aastatest. Nõukogude perioodil õpetati võõrkeeli valdavalt grammatika-tõlke meetodil (ingl grammar-translation method), mille põhirõhk oli grammatika kui olulisima keelekomponendi omandamisel. Viimastel aastakümnetel asendus see kommunikatiivse lähenemisviisiga (ingl communicative approach), mille puhul on keeleõppe fookus nihkunud grammatiliselt korrektsuselt suhtlemisvalmidusele ja -oskusele (ingl fluency over accuracy). Kommunikatiivne lähenemine keeleõppele eeldab varasemast teistsuguste õpiülesannete, õpetamismeetodite ja õpistrateegiate kasutamist.

Eesti koolinoored õpivad inglise keelt huviga. Seda õpihuvi toetab ka ümbritsev globaalne ingliskeelne ruum - internet, meedia, muusika, filmid. Seda, kuidas noored võõrkeelt õpivad, mis strateegiaid nad selleks kasutavad ja kuidas on nende õpistrateegiate kasutus seotud õpitulemustega, pole Eestis seni põhjalikumalt uuritud. Et keeleõpe oleks edukam, on vaja välja selgitada, millised õpistrateegiad tagavad paremad õpitulemused, ja neid ka praktikas rakendada. Samuti pole autoritele teadaolevalt loodud Eestis ühtegi valiidset keeleõppestrateegiate mõõdikut, millega oleks võimalik mõõta õppijate strateegiakasutust. Seega seati uuringu eesmärgiks kontrollida eri keeleõppestrateegiate taksonoomiate kehtivust, tuginedes uuringu käigus kogutud empiirilistele andmetele. Ühtlasi soovitakse kontrollida kasutatavate keeleõppestrateegiate ja õpitulemuste seost. Selleks analüüsitakse abiturientidest koosneva valimi põhjal nende eneseraporteeritud keeleõppestrateegiate kasutust mitte-testi olukorras ja nende strateegiate seotust õpitulemustega, võttes aluseks inglise keele riigieksami tulemused. 


\section{Teoreetiline raamistik}

\section{Keeleõppestrateegiad}

Õpistrateegiaid kui õppija teadlikult valitud ja rakendatud tegevusi õpiprotsessi käigus on püütud selgitada paljude definitsioonide ja klassifikatsioonide kaudu. Ühe enim kasutatud definitsiooni järgi on õpistrateegiad õppija valitud tegevused, mis aitavad tal informatsiooni omandada, säilitada, meenutada ja kasutada (Dansereau, 1985; Rigney, 1978). Kuigi see definitsioon hõlmab peaaegu kõiki õpistrateegia põhitunnuseid, lisab Oxford (1990, lk 8) neile veel selle, et õigete õpistrateegiate valik teeb õpiprotsessi õppija jaoks kergemaks, kiiremaks, nauditavamaks, enesejuhitavamaks, tõhusamaks ning uutesse olukordadesse ülekantavaks. Ka klassifikatsioone, mida on õpistrateegiate rühmitamiseks kasutatud, on erinevaid. Nii näiteks eristatakse kognitiivses psühholoogias kognitiivseid ja metakognitiivseid strateegiaid. Sellist jaotust peetakse oluliseks eelkõige seetõttu, et efektiivne strateegiate õpetamine nõuab mõlemat tüüpi strateegiate valdamist (O’Malley \& Chamot, 2002, lk 99). Samas on ka välja toodud, et strateegiate õpetamine ei ole alati tulemuslik. Browni ja Palincsari (1982) arvates on selle põhjuseks asjaolu, et kognitiivseid ja metakognitiivseid strateegiaid ei suudeta omavahel piisavalt hästi kombineerida. Nii võib tekkida olukord, kus metakognitiivsete õpistrateegiate oskamatu kasutamine põhjustab kognitiivsete strateegiate vähese tulemuslikkuse. Kuna strateegiate jaotust kognitiivseteks ja metakognitiivseteks on peetud liiga üldiseks ning see ei kata kõiki keeleõppe võimalusi ja nüansse, on see lähenemisviis põhjustanud ulatuslikke arutelusid strateegiate funktsioonide, nende kasutajate eripärade ja õpetamistingimuste üle (O’Malley \& Chamot, 2002, lk 99). Ent strateegiaid eristatakse ka teistel alustel, näiteks jaotas Dansereau (1985) keeleõppestrateegiad primaarseteks ja tugistrateegiateks. Oma sisult on sellel jaotusel suuri kokkulangevusi Oxfordi (1990) otseste ja kaudsete strateegiatega. Nii Dansereau primaarsed strateegiad kui ka Oxfordi otsesed strateegiad on kombinatsioonid kognitiivsetest õpistrateegiatest, tugi- ja kaudsed strateegiad aga koondavad enda alla sotsiaal-afektiivsed ja metakognitiivsed strateegiad.

Järgnevalt antakse ülevaade Oxfordi (1990) keeleõppestrateegiate klassifikatsioonist ja SILList kui kõige tuntumast ja enim kasutatud õpistrateegiate uurimise vahendist keeleõppes. 


\section{Keeleõppestrateegiate taksonoomiad, SILL ja selle valiidsusuuringud}

Oxford jagas keeleõppestrateegiad esialgu kahte suurde rühma: otsesteks ja kaudseteks strateegiateks. Mõlemal oli omakorda kolm alarühma: kognitiivsed, mälu- ja kompensatsioonistrateegiad otseste strateegiate rühmas ning metakognitiivsed, afektiivsed ja sotsiaalsed strateegiad kaudsete strateegiate rühmas (joonis 1). Kuigi Oxford eristab oma otseste strateegiate jaotuses kognitiivseid, mälu- ja kompensatsioonistrateegiaid, siis sisult langevad need suures osas kokku. Mitmed teised uurijad ongi paigutanud mälustrateegiad kognitiivsete strateegiate alla (nt O’Malley \& Chamot, 2002; Phakiti, 2003; Purpura, 1997).

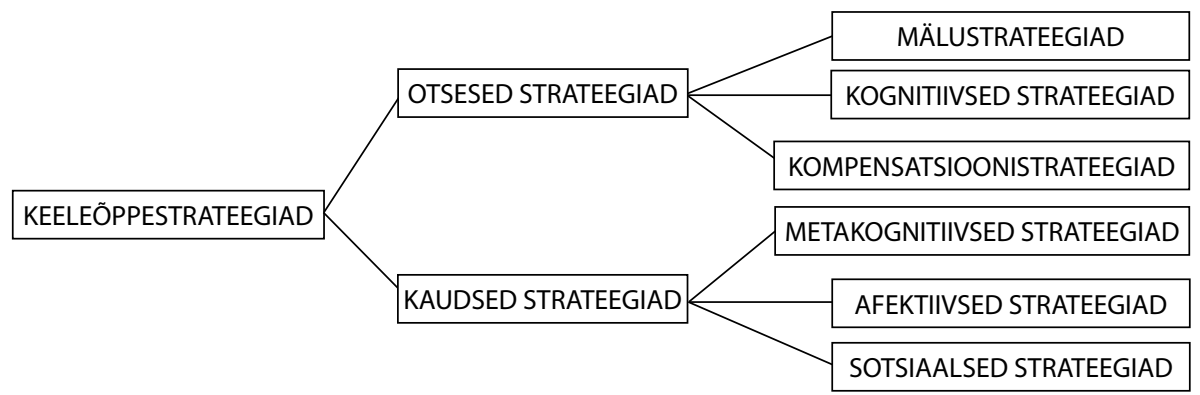

Joonis 1. Keeleõppestrateegiad (Oxford, 1990, lk 17-21 järgi)

Sama taksonoomia oli Oxfordil aluseks ka keeleõppestrateegiate loendi SILL (Strategy Inventory for Language Learning) loomisel. SILLi peetakse kasulikuks keeleõppestrateegiate mõõtevahendiks, kuna selle abil on suudetud näidata seost rakendatavate õpistrateegiate ja õpiedu vahel (Oxford \& Burry-Stock, 1995). See on andnud ka võimaluse väita, et toetades õppijate strateegiakasutust, saab toetada ka nende keeleoskuse arengut. Varased SILLi valiidsusuuringud on näidanud head sisereliaablust kõigi alamskaalade korral - see jääb vahemikku 0,68-0,8 (Green \& Oxford, 1995; Hsiao \& Oxford, 2002; Saks, Leijen, Õun, \& Täht, 2015; Tragant, Thomson, \& Victori, 2013).

Et uurida SILLi aluseks olevat keeleõppestrateegiate taksonoomiat, tegid Hsiao ja Oxford (2002) kinnitava faktoranalüüsi. Selle tulemused näitasid, et kuuefaktoriline struktuur oli õppijate strateegiakasutuse puhul kõige püsivam. Ometi tunnistasid autorid, et mudeli headuse näitajad ei olnud siiski kõige paremad ning kogu instrumendi struktuuri ja formaati tuleks veel uurida (Hsiao \& Oxford, 2002).

Ka mitmed teised uurijad on SILLi reliaabluse kahtluse alla seadnud, kuna pole leidnud kindlat tõestust keeleõppestrateegiate kuuefaktorilise 
struktuuri kohta (Park, 2011; Rose, 2012; Saks et al., 2015; Woodrow, 2005). Park (2011) ja Saks jt (2015) väidavad, et SILLi laialdaselt kasutatav kahe- ja kuuejaotuseline klassifikatsioon ei sobitu andmetega ja seetõttu tuleks keeleõppestrateegiate struktuuri paremaks mõistmiseks SILLi ülesehitust muuta.

Teised uurijad on pakkunud keeleõppestrateegiate süstematiseerimiseks teistsuguseid teid. Näiteks eristab Cohen (1996) keele óppimise strateegiaid ja keele kasutamise strateegiaid. Koos rakendatuna moodustavad need tegevused, mida keeleõppija valib, et parandada ja toetada oma võõrkeele õpiprotsessi, võõrkeele kasutamist või mõlemat. Coheni (1996) sõnutsi aitavad keele õppimise strateegiad parandada õppija teadmisi, keele kasutamise strateegiad aga keskenduvad keeleteadmiste rakendamisele suhtlussituatsioonides. Kui keele õppimise strateegiad hõlmavad tegevusi õpitava materjali määratlemiseks, siis keele kasutamise strateegiad rakenduvad materjali meeldetuletamise, harjutamise, toimetuleku ja suhtlusolukordades.

Veel üks võimalus klassifitseerida keeleõppestrateegiaid on lähtumine funktsioonist. O’Malley ja Chamot (2002, lk 44-46) toovad kognitiivsele teooriale tuginedes välja kolm strateegiate rühma: kognitiivsed, metakognitiivsed ja sotsiaal-afektiivsed strateegiad. Need strateegiad on sisult suhteliselt sarnased SILLi strateegiatega, kuid O’Malley ja Chamot kirjeldavad neid strateegiaid põhjalikumalt.

Lähenemisviiside erinevustest hoolimata on kõigi klassifikatsioonide puhul suuri kattuvusi ning üldjoontes saab rääkida eelkõige kahest suurest strateegiate rühmast: kognitiivsetest ja metakognitiivsetest strateegiatest. Need jagunevad omakorda alarühmadeks, mis eri autorite taksonoomiates on mõneti erinevad. Strateegiarühmade eristamise teeb keeruliseks strateegiate mitmemõõtmelisus ja omavaheline seotus, mis toob kaasa ulatuslikud kattuvused taksonoomiates. Siinses töös lähtutakse sobivaima struktuuri otsingul eri taksonoomiatest ning püütakse leida ühisjooni kirjeldatud strateegiate sisus.

\section{Keeleõppestrateegiate seos õpitulemustega}

Keeleõppe tulemuslikkust mõõdetakse valdavalt testidega. Hinnang õppimise tulemuslikkuse kohta esitatakse arvuliselt väljendatava tulemuse ehk punktisummana. Testidega mõõdetavat õpiedu mõjutavad kahesugused strateegiad: õpistrateegiad ja testi tegemise strateegiad (Cohen, 2006). Kuigi keeleõppestrateegiaid on maailmas palju uuritud, ei ole tekkinud ühist arusaama, kuidas on õppija õpistrateegiate kasutus seotud tema keelekasutuse edukusega ning kuidas peegeldavad keeletesti tulemused tema strateegiakasutust. 
On leitud, et õpistrateegiate kasutus ja ópiedu on omavahel seotud, kuid need seosed on väga komplekssed, raskesti hoomatavad ja kirjeldatavad (Wesche, 1987). Selle üheks põhjuseks peetakse konstrukti mitmemõõtmelist olemust ja muutujatevahelisi interaktsioone (Chamot, Kupper, \& Impink-Hernandez, 1988), samuti asjaolu, et keerulisemad õpiülesanded eeldavad õppijalt mitme õpistrateegia üheaegset kasutamist ning erinevate vaimsete protsesside aktiveerimist (Dansereau, 1985). Pea kõik uurijad on üksmeelel selles, et metakognitsioonil on täita keeleõppes tähtis osa, kuid see, kuidas on metakognitiivsed õpistrateegiad seotud kognitiivsetega ning kuidas nad panustavad õpitulemustesse, ei ole kaugeltki mitte üheselt mõistetav (Zhang, Goh, \& Kunnan, 2014). Purpura (1997), kes uuris kognitiivsete ja metakognitiivsete õpistrateegiate seotust lugemistesti tulemustega, leidis, et kognitiivsed õpistrateegiad ei mõjuta otseselt lugemisoskuse edukust, kuid teevad seda kaudselt läbi sõnavara- ja grammatikaoskuse. Mälustrateegiatel oli otsene negatiivne seos sõnavara- ja grammatikaoskusega, mis tähendab, et mälustrateegiate kasutamine pingelises testitegemise olukorras halvendab testi tulemust. Metakognitiivsetel õpistrateegiatel ei leitud otsest seost testi tulemuslikkusega, küll aga olid need otseselt ja positiivselt seotud kognitiivsete strateegiate kasutusega, mõjutades testi tulemuslikkust kaudselt, kognitiivsete strateegiate kaudu (Purpura, 1997). Sarnasele kognitiivsete ja metakognitiivsete õpistrateegiate seotusele osutas oma uuringus ka Phakiti (2003). Bachman ja Palmer (2010, lk 117) näitasid, et testitegija metakognitiivsete strateegiate kasutus määrab ära selle, kuidas keelevõimekust keelekasutuse situatsioonis suudetakse realiseerida. Keelevõimekuse all mõistetakse õppija keeleteadmiste ja strateegiliste oskuste ehk metakognitiivsete oskuste kombinatsiooni (Bachmann \& Palmer, 2010, lk 78). Ka Flavell (1979) märkis, et metakognitsioonil on oluline roll paljude kognitiivsete tegevuste sooritamisel keeleõppe ja keelekasutuse, sealhulgas testi tegemise olukorras.

Kõigi eelnimetatud uuringutega sooviti kontrollida keeleõppijate lugemispädevust ning sellega seotud sõnavara- ja grammatikapädevust. Seda, kas sarnast õpistrateegiate seotust võiks laiendada ka teistele keelepädevustele (kuulamine, kirjutamine ja rääkimine), püütaksegi praeguse uuringuga teada saada. Eesmärk on välja selgitada, kas ja kuivõrd on keeleõppestrateegiad seotud standardiseeritud testi abil mõõdetavate õpitulemustega. 


\section{Standardiseeritud testid}

Standardiseeritud test on test, mis viiakse läbi ja mida hinnatakse kokkuleppeliselt kõikjal ühtmoodi. Standardiseerituse eesmärk on tulemuste võrreldavus (Johnson \& Rao, 2010, lk 853). Eesti koolilõpetajad peavad gümnaasiumi lõpetamiseks sooritama positiivsele tulemusele (vähemalt 1 punkt) kolm standardiseeritud riigieksami testi: eesti keele, matemaatikaja võõrkeeletesti.

\section{Inglise keele riigieksam}

Inglise keele riigieksami eesmärk on tagada eksamitulemuste üleriigiline võrreldavus, võimaldada õpilastel saada objektiivsem pilt oma õpitulemustest, saada ülevaade ja anda tagasisidet õpetamise/õppimise tulemuslikkuse kohta, toetada óppekava rakendamist ja kontrollida riikliku õppekavaga kindlaksmääratud õpitulemuste saavutatust suulisest kõnest arusaamisel (kuulamisoskus), suulisel suhtlemisel (kõnelemisoskus), kirjalikust tekstist arusaamisel (lugemisoskus), kirjalikul suhtlemisel (kirjutamisoskus) ja keelestruktuuride õigel kasutamisel (Euroopa Nõukogu, 2007; Tasemetööde ..., 2010). Eksam põhineb põhikooli ja gümnaasiumi riiklikul õppekaval ja Euroopa keeleõppe raamdokumendil ning vastab Euroopa Nõukogu keeleoskustasemete B1 ja B2 kirjeldusele.

Inglise keele riigieksam koosneb neljast osast, millest kirjutamis(2 ülesannet) ja kuulamisosa (5 ülesannet) annab kumbki 25\%, lugemisosa (7 ülesannet) $30 \%$ ja suuline osa (2 ülesannet) $20 \%$ kogupunktisummast. Kirjutamisülesannetes oodatakse õppijalt oma arvamuse väljendamist, kirjeldamist, kommenteerimist, arutlemist, võrdlemist ja hinnangu andmist. Kuulamisülesanded eeldavad teksti mõttest arusaamist, detailide mõistmist ja valikulise info leidmist. Lugemisülesanded kontrollivad õppija suutlikkust loetut mõista, ka kaudselt esitatud info mõistmist, tekstisiseste seoste märkamist ja oskust tuletada tähendust kaasteksti abil. Suulise osaga hinnatakse õppijate üldist rääkimisoskust ja suulist suhtlust. Kuulamisja lugemistekstid põhinevad valdavalt meediakanalitest ja ajakirjandusest pärit autentsetel materjalidel. Õpilasele omistatakse B1 keeletase, kui ta on saavutanud $50-74 \%$ maksimumtulemusest, ja B2 tase, kui ta eksamitulemus on 75-100\% maksimumtulemusest (Euroopa Nõukogu, 2007; Inglise keele ..., 2014).

Sellises formaadis inglise keele riigieksamit on Eestis läbi viidud juba paarkümmend aastat. Kuna riigieksamitulemused on olnud olulised nii koolide taseme hindamisel kui ka ülikooli sisseastumisel, siis on koolid oma võõrkeeleõppes tugevalt orienteeritud parima tulemuse saavutamisele. 
See on omakorda kaasa toonud keeleõppe orienteerituse eksami ülesehitusele ja ülesannetele.

Uurimuse eesmärk on leida empiirilistele andmetele kõige paremini vastav keeleõppestrateegiate taksonoomiate mudel (Est-SILL), mis võimaldab mõõta eestlastest keeleõppijate tajutavaid õpistrateegiaid ja mõista nende seost õpitulemustega. Õpistrateegiate ja -tulemuste seoste uurimiseks loodi struktuurivõrrandite meetodil kolm mudelit. Analüüsi käigus võrreldi nende mudelite valiidsust ja sobivust kogutud andmetega ning uuriti strateegiarühmade mõju inglise keele riigieksamiga mõõdetavatele õpitulemustele. Uuringu eesmärgist lähtudes püstitati järgmised uurimisküsimused.

1. Missugune on eesti keelde tõlgitud ja kohandatud keeleõppestrateegiate küsimustiku faktorstruktuur?

2. Kuidas on Est-SILLiga mõõdetud keeleõppestrateegiad seotud inglise keele kui võõrkeele õppijate õpitulemustega nelja keelepädevuse (kuulamise, lugemise, kirjutamise ja rääkimise) lõikes?

\section{Metoodika}

\section{Valim}

Uuringu valimisse kuulus 383 Pärnu gümnaasiumiõpilast, kellest 269 (71\%) olid küsitluse läbiviimise päeval koolis ja täitsid küsitluse. Kõik 269 küsitluse vormi olid korralikult täidetud ning neid sai tulemuste analüüsis kasutada. Kuigi see valim ei pruugi olla representatiivne kogu populatsiooni tähenduses, annab see hea ülevaate ühe Eesti keskmise suurusega linna lõpuklasside õpilaste keeleõppestrateegiate kasutusest. Õpilaste keskmine vanus oli $18,4(S H=0,5)$. Noormehi ja tütarlapsi oli valimis peaaegu võrdselt: vastavalt $45 \%$ ja $55 \%$. Inglise keelt olid nad selleks ajaks õppinud umbes kümme aastat $(M=10,22 ; S H=1,3)$.

\section{Uuringu protseduur}

Uuringu läbiviimiseks pöörduti kõigi Pärnu linna gümnaasiumide abiturientide poole. Kõigepealt paluti nõusolekut õpilaste anketeerimiseks kõigi koolide juhtkondadelt. Andmeid koguti vabatahtlikkuse alusel. Õpilastele selgitati, et andes allkirja nõusolekulehele, annavad nad uurijatele loa analüüsida küsimustiku andmeid kooskõlas nende tulevase, 2014. aasta mais toimuva inglise keele riigieksami tulemustega. Uuringu läbiviija andis osalejatele küsimustiku kohta juhiseid ja väljendas valmisolekut vastata 
küsimustele küsimustiku täitmise ajal. Kõik osalejad täitsid paberküsimustiku individuaalselt uuringu läbiviija juuresolekul. Küsimustiku täitmine võttis aega 25-30 minutit.

\section{Instrument}

Enesekohase küsimustiku SILL originaalversioon sisaldab 50 väidet. Need väljendavad õppija tegevusi ehk õpistrateegiaid, mida õppijad kasutavad võõrkeelt õppides. Väited on jaotatud kuude rühma (A-F) vastavalt Oxfordi strateegiate taksonoomiale: mälustrateegiad, kognitiivsed strateegiad, kompensatsioonistrateegiad, metakognitiivsed strateegiad, afektiivsed strateegiad ja sotsiaalsed strateegiad (Oxford, 1990, lk 293-296). Vastajad hindavad kõigi väidete tõesust enda õpikogemuse põhjal viiepallisel Likerti skaalal, kus 1 tähistab vastust „Mitte kunagi või peaaegu mitte kunagi õige” ja 5 vastust „Alati või peaaegu alati õige”. Küsimustik algab lühikese sissejuhatusega, kus vastajatele tutvustatakse küsimustiku eesmärki. Vastajaid julgustatakse vastama võimalikult tõeselt ning neile selgitatakse, et esitatud väidetele pole õigeid või valesid vastuseid.

SILLi kohandamisel eesti keele tarbeks kasutati Guillemini jt (1993) loodud viieastmelise metoodika kohandatud versiooni. Selle protsessi käigus tõlgiti originaalinstrument eesti keelde, seejärel tegid kolm sõltumatut tõlkijat tagasitõlke inglise keelde, veendumaks, et tõlgitud versioon annab terminite sisu sama moodi edasi kui originaalversioon. Järgmisena hinnati, analüüsiti ja võrreldi algteksti tagasitõlke tekstidega ning eestikeelne tekst läbis sisutoimetamise ja keelekorrektuuri. Eeltestimisel paluti vastajatel hinnata väidete selgust ja üheselt mõistetavust. Kohandamisprotsessi käigus ei tehtud küsimustikus suuri muudatusi. Peaaegu kõik originaalversioonis kasutatud ja eesti keelde tõlgitud terminid olid Eesti võõrkeeleõppijatele tuttavad ning neid mõisteti üheselt. Ainust muudatust, mis kohandamisprotsessis tehti, selgitatakse alljärgnevalt.

\section{Andmeanalüïs}

Uuringu läbiviimisel rakendatud statistilistest protseduuridest annab ülevaate joonis 2 . 


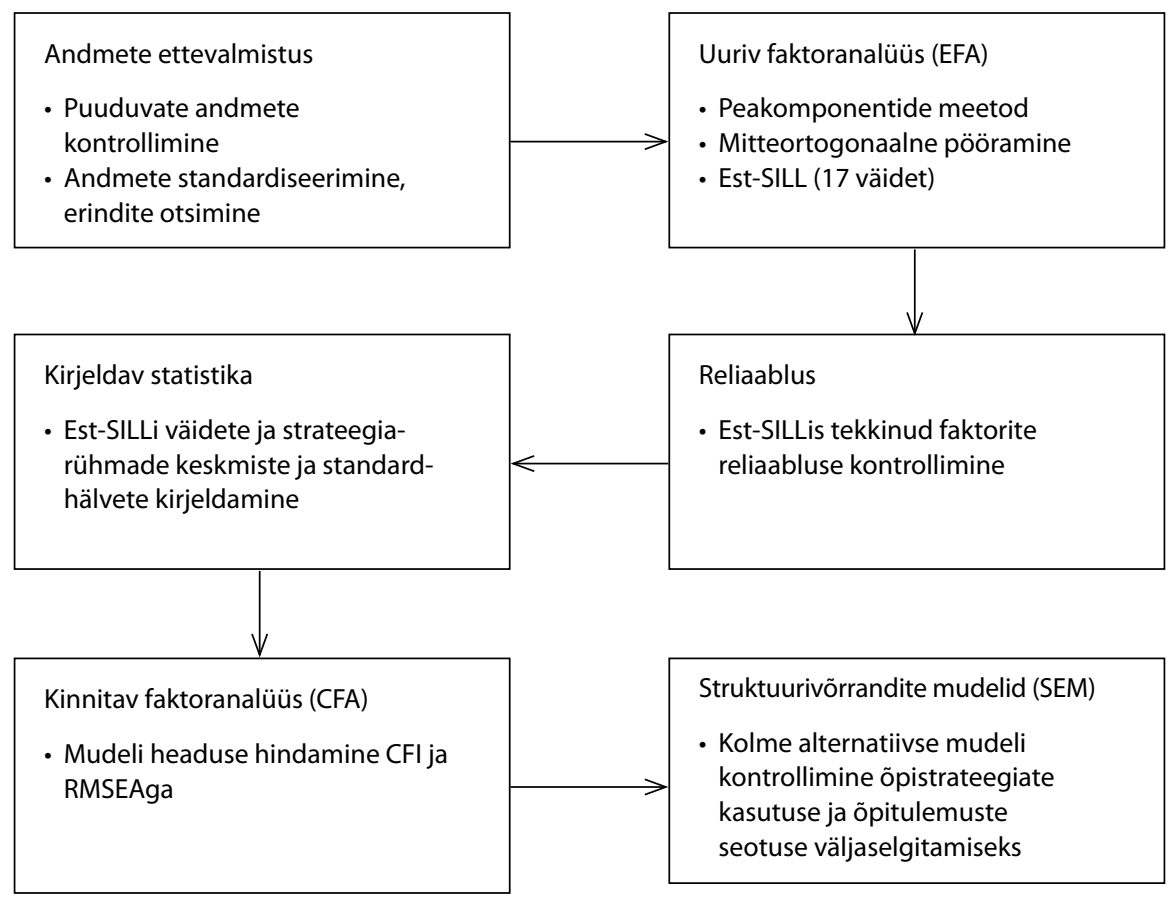

Joonis 2. Uuringus rakendatud statistilised protseduurid

Enne statistilist analüüsi standardiseeriti kõik andmed ja otsiti võimalikke erindeid. Selle uuringu andmestikus ilmneski mitmeid erindeid, millest üks oli nii tugev, et tuli analüüsist välja jätta. See oli afektiivsete õpistrateegiate rühma kuulunud 43. väide Ma kirjutan oma tunded üles ópipäevikusse. See väide jäeti välja, toetudes vastajate tagasisidele: vastajad ei tundnud õpipäeviku mõistet ning seetõttu ei osanud sellele väitele vastata. Ühtlasi eristus see väide standardiseerimisprotsessi käigus ka tugeva erindina. Põhjus, miks Eesti kooliõpilastel oli raske seda väidet hinnata, on tõenäoliselt asjaolu, et õpipäevikute kasutamine refleksioonivahendina pole Eesti koolitraditsioonis väga levinud ja seetõttu pole Eesti õppijatel kogemusi oma tunnete ja mõtete jagamisega õpipäeviku vahendusel.

Et vastata esimesele uurimisküsimusele eesti keelde tõlgitud ja kohandatud keeleõppestrateegiate küsimustiku SILL struktuuri kohta, viidi läbi uuriv faktoranalüüs. Selleks rakendati peakomponentide meetodit. Kuna oli tõenäoline, et tekkivad faktorid on omavahel korreleeritud, siis kasutati mitteortogonaalset (direct oblimin) pööramist. Tekkinud skaalade sisereliaablust hinnati Cronbachi alfaga, mille kriteeriumi väärtus on 0,6 (Nunnally \& Bernstein, 1994). Et leida, kuivõrd ulatuslikult sobitub lahend uuritavate andmetega, kontrolliti tulemust kinnitava faktoranalüüsiga. 
Mudeli sobivust andmetega näitavad kinnitava faktoranalüüsi puhul sobivus- ehk headusindeksid. Siinses töös kasutati sobivusindekseid CFI (comparative fit index) ja RMSEA (root mean square error of approximation). Mudeli sobivust andmetega võib pidada heaks, kui CFI $\geq 0,9$ ja RMSEA $\leq$ 0,06 (Hu \& Bentler, 1999). Kui RMSEA on suurem kui 0,08, ei ole viga enam aktsepteeritav (Brown, 2006).

Et vastata teisele uurimisküsimusele õppijate keeleõppestrateegiate ja õpitulemuste vaheliste seoste kohta, loodi kolm struktuurivõrrandite mudelit ja seejärel kontrolliti neid. Mudelite loomisel võeti arvesse varasemates uurimustes kirjeldatud mudeleid ning analüüsid tehti tarkvaraprogrammidega SPSS 20 ja AMOS. Esimene, ühetasandiline mudel (joonis 3) loodi eeldusel, et kõik õpistrateegiate rühmad panustavad otseselt nelja keelepädevuse õpitulemustesse. Teisisõnu, kognitiivsed ja metakognitiivsed ópistrateegiad toimivad sünergias, mõjutades testi tulemuslikkust.

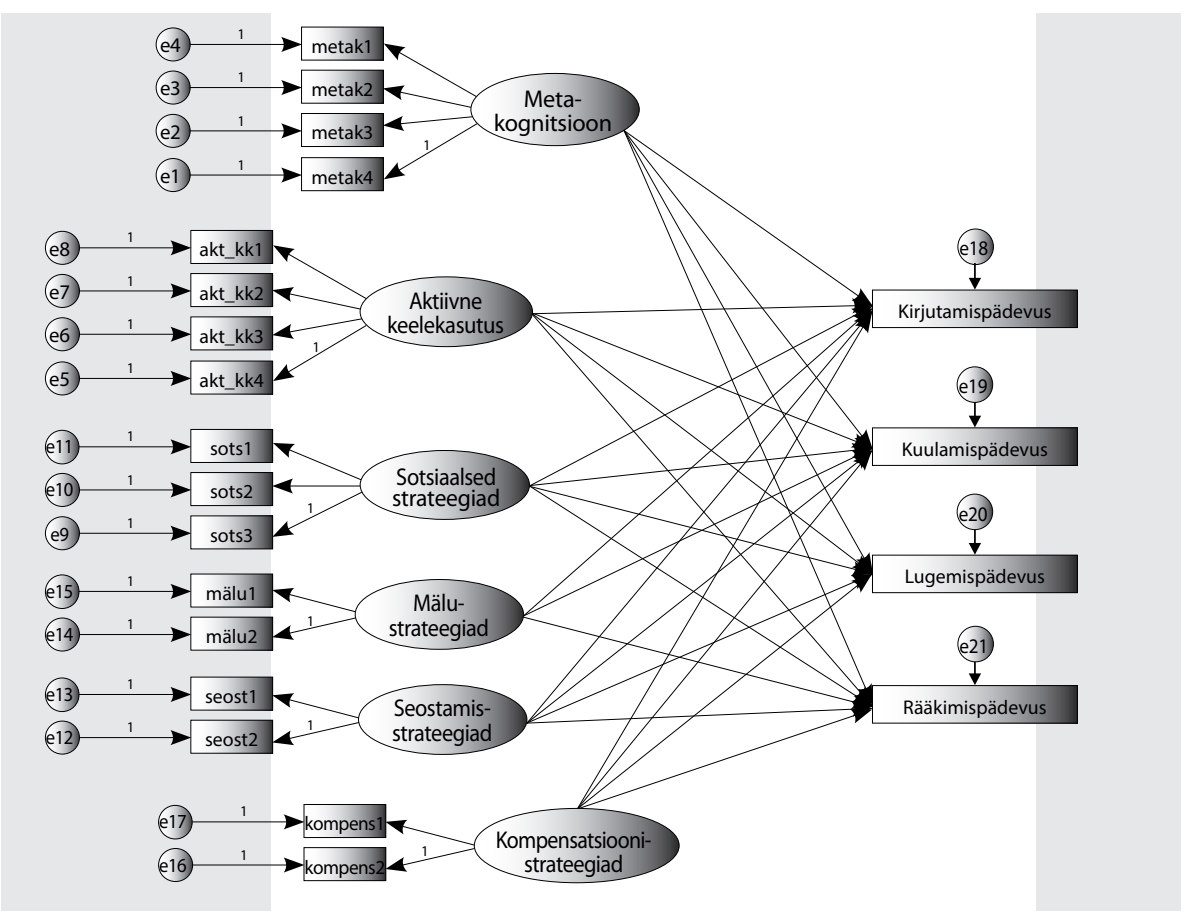

Joonis 3. Ühetasandiline mudel 
Teisena loodi hierarhiline mudel (joonis 4), mille puhul eeldati, et õpitulemusi mõjutavad kolm strateegiarühma: kognitiivsed, metakognitiivsed ja sotsiaalsed õpistrateegiad. Sellisel puhul hõlmavad kognitiivsed strateegiad aktiivse keelekasutuse, kompensatsiooni-, mälu- ja seostamisstrateegiaid, mis ühiselt panustavad õpitulemustesse. Niisugusest strateegiate jaotusest on lähtunud paljud keeleõppe uurijad (Brown, Bransford, Ferrara, \& Campione, 1983; O’Malley \& Chamot, 2002; Rigney, 1978).

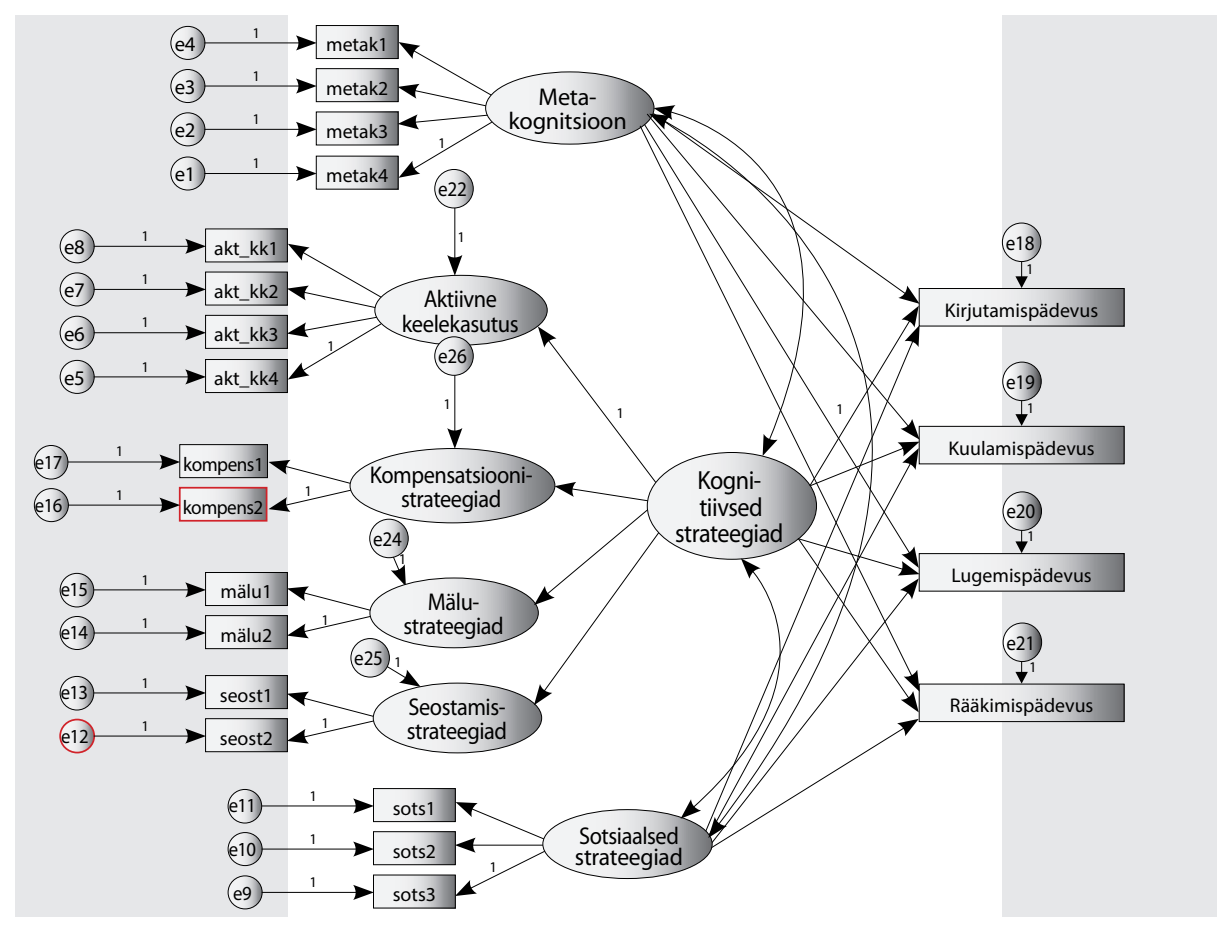

Joonis 4. Hierarhiline mudel

Kolmanda, vahendatud mudeli loomisel (joonis 5) lähtuti teoorial põhinevatest teadmistest õpitulemusi otseselt ja kaudselt mõjutavate õpistrateegiate kohta (Purpura, 1997; Zhang et al., 2014). Mudeli loomisel võeti aluseks korrelatsioonianalüüsi tulemused. Korrelatsioonikordajad näitasid, et metakognitiivsed ja kompensatsioonistrateegiad on küll seotud teiste õpistrateegiate rühmadega, kuid mitte õpitulemustega. Seetõttu peeti vajalikuks kontrollida, kas metakognitiivsed ja kompensatsioonistrateegiad mõjutavad õpitulemusi otseselt või kaudselt, teiste strateegiarühmade kaudu. 


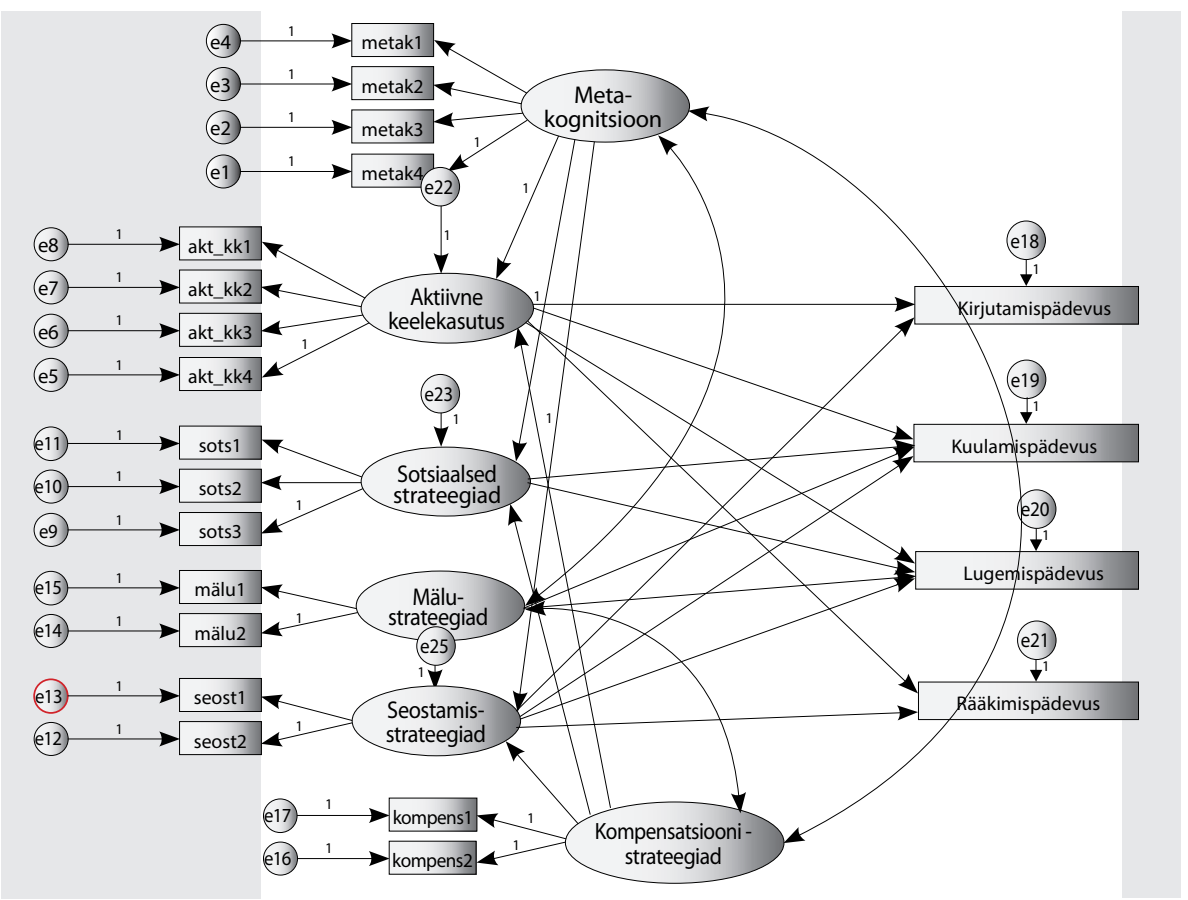

Joonis 5. Vahendatud mudel

\section{Tulemused}

\section{Uuriv faktoranalüïs}

Uuriv faktoranalüüs viidi läbi peakomponentide meetodil mitteortogonaalse pööramisega. Analüüsi käigus jäeti otsitavate faktorite arv lahtiseks, kuid Kaiseri kriteeriumi järgi (omaväärtus peab olema vähemalt 1) võis oodata kuuefaktorilist lahendit. Pärast mitmekordset puhastamist väikeste faktorlaadungitega $(<0,5)$ tunnustest saadi kuuefaktoriline lahend (tabel 1$)$, mille kirjeldusvõime oli $68 \%$.

Tekkinud skaalas (Est-SILL) on algse 50 tunnuse asemel 17 (lisa 1). Faktorite alla kuuluvad aktiivne keelekasutus (strateegiad, mis väljendavad õppija algatatud keelekasutust reaalelulistes olukordades, ning kombinatsioon Oxfordi kognitiivsetest ja sotsiaalsetest õpistrateegiatest), metakognitiivsed strateegiad (väljendavad õpitegevuse planeerimist, jälgimist ja hindamist), sotsiaalsed strateegiad (kasutatakse abi küsimiseks ja andmiseks õpisituatsioonis), kompensatsioonistrateegiad (nende abil ületatakse lünki teadmistes), mälustrateegiad (mälutehnilised võtted, mis aitavad paremini meelde jätta uut materjali) ja seostamisstrateegiad (kasutatakse 
varem õpitu aktiveerimiseks ja seostamiseks uue õpitava materjaliga). Afektiivsed strateegiad jäid uuriva faktoranalüüsi lahendist välja. Kuna on teada, et afektiivseid õpistrateegiaid kasutavad valdavalt algajad keeleõppijad (Oxford, 1990), siis oli nende väljajäämine ligikaudu kümme aastat keelt õppinud inimeste puhul ootuspärane.

Tabel 1. Est-SILLi elementide faktorlaandungid ja kirjeldatud variatiivsus $\left(R^{2}\right)$

\begin{tabular}{l|c|c|c|c|c|c|c}
\hline \multirow{2}{*}{} & \multicolumn{5}{c}{ Komponent } & \\
\cline { 2 - 7 } & 1 & 2 & 3 & 4 & 5 & 6 & $R^{2}$ \\
\hline akt_kk1 & $-0,831$ & & & & & & 0,73 \\
\hline akt_kk2 & $-0,775$ & & & & & & 0,64 \\
\hline akt_kk3 & $-0,555$ & & & & & & 0,64 \\
\hline akt_kk4 & $-0,546$ & & & & & & 0,54 \\
\hline metak1 & & 0,843 & & & & & 0,72 \\
\hline metak2 & & 0,823 & & & & & 0,68 \\
\hline metak3 & & 0,731 & & & & & 0,63 \\
\hline metak4 & & 0,715 & & & & & 0,71 \\
\hline sots1 & & & 0,788 & & & & 0,65 \\
\hline sots2 & & & 0,756 & & & & 0,68 \\
\hline sots3 & & & 0,753 & & & & 0,65 \\
\hline kompens1 & & & & 0,830 & & & 0,64 \\
\hline kompens2 & & & & 0,748 & & & 0,74 \\
\hline mälu1 & & & & & 0,859 & & 0,75 \\
\hline mälu2 & & & & 0,853 & & 0,78 \\
\hline seostamis1 & & & & & & 0,810 & 0,68 \\
\hline seostamis2 & & & & & 0,728 & 0,67 \\
\hline
\end{tabular}

\section{Reliaablus}

Sisereliaabluse analüüsi tulemused näitasid, et Est-SILLi faktoritesse kuuluvad tunnused mõõdavad sarnaseid keeleõppestrateegiate karakteristikuid. Ainsad alfa koefitsiendid, mis jäid alla aktsepteeritava 0,6 taseme (Nunnally \& Bernstein, 1994), olid kompensatsiooni- ja seostamisstrateegiatel, vastavalt 0,51 ja 0,59 (tabel 2). Väike koefitsient võib olla põhjustatud väikesest tunnuste arvust $(N=2)$, mis need faktorid moodustavad. 
Tabel 2. Est-SILLi faktorite sisereliaablus ja kirjeldatud variatiivsus

\begin{tabular}{l|c|c|c}
\hline & Cronbachi alfa & Kirjeldatud variatiivsus & Tunnuste arv \\
\hline Aktiivne keelekasutus & 0,75 & $27,6 \%$ & 4 \\
\hline Metakognitiivsed strateegiad & 0,82 & $10,7 \%$ & 4 \\
\hline Sotsiaalsed strateegiad & 0,72 & $9,2 \%$ & 3 \\
\hline Kompensatsioonistrateegiad & 0,51 & $8,3 \%$ & 2 \\
\hline Mälustrateegiad & 0,68 & $6,8 \%$ & 2 \\
\hline Seostamisstrateegiad & 0,59 & $5,2 \%$ & 2 \\
\hline
\end{tabular}

\section{Kirjeldav statistika}

Küsimustikule vastajad hindasid oma keeleõppestrateegiate kasutust viiepallisel Likerti skaalal, kus 1 tähistas vastust „Mitte kunagi või peaaegu mitte kunagi õige” ja 5 vastust „Alati või peaaegu alati õige”. Kui vaadata vastajate keeleõppestrateegiate kasutust tekkinud faktorite kaupa (tabel 3), siis eristuvad suurima kasutusega sotsiaalsed ja kompensatsioonistrateegiad. Väikseima kasutussagedusega on mälustrateegiad. See on mõneti ootuspärane, sest mälustrateegiaid kasutavad valdavalt algajad keeleõppijad. Selle valimi puhul oli aga tegemist kümme ja enam aastat õppinud inimestega.

Tabel 3. Strateegiate kasutust väljendav kirjeldav statistika $(N=269)$

\begin{tabular}{l|c|c|c|c}
\hline & Keskmine & Standardhälve & Skewness & Kurtosis \\
\hline Sotsiaalsed strateegiad & 3,73 & 1,07 & $-0,69$ & $-0,06$ \\
\hline Kompensatsioonistrateegiad & 3,53 & 0,88 & $-0,21$ & $-0,41$ \\
\hline Aktiivne keelekasutus & 3,44 & 0,93 & $-0,14$ & $-0,61$ \\
\hline Metakognitiivsed strateegiad & 3,40 & 1,05 & $-0,37$ & $-0,45$ \\
\hline Seostamisstrateegiad & 3,30 & 0,77 & $-0,24$ & 0,19 \\
\hline Mälustrateegiad & 1,45 & 0,71 & 2,01 & 4,88 \\
\hline
\end{tabular}

Väidete lõikes oli suurima keskmise väärtusega metakognitiivsete strateegiate hulka kuuluv „Ma püüan saada paremaks võõrkeele õppijaks” $(M=4,19 ; S D=0,96)$. Sellele järgnesid sotsiaalsed strateegiad „Kui ma ei saa millestki võõrkeeles aru, siis ma palun inimesel rääkida aeglasemalt või palun tal seda korrata” $(M=3,99 ; S D=1,02)$ ja „Ma palun vajadusel võõrkeeles kõnelevalt inimeselt abi" $(M=3,69 ; S D=1,16)$ ning 
kompensatsioonistrateegia „Mõistmaks uusi võõrkeelseid sõnu, püüan ma tähendust ära arvata" $(M=3,63 ; S D=1,03)$. Väikseima kasutussagedusega olid mälustrateegiad „Ma kasutan uute võõrkeelsete sõnade meeldejätmiseks sõnakaarte” $(M=1,42 ; S D=0,79)$ ja „Ma kasutan võõrkeelsete sõnade meeldejätmiseks liigutusi" ( $M=1,47 ; S D=0,82)$ ning metakognitiivne strateegia "Ma planeerin oma tegevust, et mul oleks piisavalt aega võõrkeelt õppida" $(M=2,62 ; S D=1,04)$. Est-SILLi kuuluvast 17 väitest 13 keskmine väärtus oli üle 3 (skaalal 1-5), ainult nelja väite keskmised jäid sellest allapoole.

\section{Kinnitav faktoranalüïis}

Uuriva faktoranalüüsiga saadud keeleõppestrateegiate mudeli headust kontrolliti kinnitava faktoranalüüsiga. Selleks rakendati suurima tõepära meetodit. Mudeli headuse näitajad olid head: $\chi^{2}$-statistiku ja vabadusastmete suhe jäi alla 3,0 piiri $\left(\chi^{2}=201,405 ; d f=103\right.$; CMIN/DF $\left.=1,96\right)$, CFI oli 0,92, mida võib pidada heaks tulemuseks, ja RMSEA oli 0,06, mis jääb samuti aktsepteeritavasse vahemikku (Brown, 2006). Faktoranalüüsiga kinnitatud mudel on toodud lisas 2.

\section{Struktuurivõrrandite mudelid}

Keeleõppijate õpistrateegiate kasutuse seotust nende õpitulemustega uuriti struktuurivõrrandite meetodi abil. Teooriale tuginedes loodi kolm alternatiivset mudelit: ühetasandiline, hierarhiline ja vahendatud mudel. Ühetasandilise mudeli (joonis 3) eeldus oli, et kõik kuus õpistrateegiate rühma panustavad kõigi nelja keelepädevuse õpitulemustesse ühtmoodi ja otseselt. Hierarhilise mudeli (joonis 4) puhul on aktiivse keelekasutuse, kompensatsiooni-, mälu- ja seostamisstrateegiate rühmad koondatud kognitiivseteks strateegiateks. Kolmas, vahendatud mudel (joonis 5) põhineb teoorial, mille kohaselt osa strateegiaid ei panusta õpitulemustesse mitte otseselt, vaid kaudselt, st teiste strateegiate kaudu. Selle mudeli loomisel olid aluseks strateegiatevaheliste seoste korrelatsioonikordajad.

Nagu näha tabelist 4, sobituvad ühetasandiline ja vahendatud mudel andmetega hästi.

Tabel 4. Mudelite headuse näitajad SEMi tulemuste põhjal

\begin{tabular}{l|c|c|c|c|c}
\hline & $x^{2}$ & $d f$ & CMIN/DF & CFI & RMSEA \\
\hline Ühetasandiline mudel & 257,620 & 152 & 1,70 & 0,95 & 0,05 \\
\hline Hierarhiline mudel & 398,329 & 175 & 2,28 & 0,89 & 0,07 \\
\hline Vahendatud mudel & 242,953 & 161 & 1,51 & 0,96 & 0,04 \\
\hline
\end{tabular}


Kuigi ühetasandilise mudeli ja vahendatud mudeli headuse näitajad olid peaaegu võrdselt head, siis teooriat ning strateegiate ja õpitulemuste vahelisi korrelatsioonikordajaid arvesse võttes jätkati vahendatud mudeli analüüsiga. Eelkõige pakkus huvi strateegiarühmade suhe õpitulemustega ning nende otsene ja kaudne mõju.

Analüüsi käigus ilmnes, et aktiivse keelekasutuse strateegiatel on tugevaim positiivne otsene mõju õpitulemustele (tabel 5). Sotsiaalsete ja seostamisstrateegiate mõju õpitulemustele on küll otsene, kuid negatiivne. Samuti avaldavad mälustrateegiad negatiivset mõju lugemistesti tulemusele. See tähendab, et mida vähem kasutati näiteks sotsiaalseid või seostamisstrateegiaid õpiolukorras, seda paremad olid vastavad õpitulemused riigieksamil. Siiski on sotsiaalsete ja mälustrateegiate mõju väga väike.

Tabel 5. Standardiseeritud otsene ja kaudne mõju

\begin{tabular}{l|c|c|c|c|c|c}
\hline & $\begin{array}{c}\text { Kompen- } \\
\text { satsiooni- } \\
\text { stra- } \\
\text { teegiad }\end{array}$ & $\begin{array}{c}\text { Mälu- } \\
\text { stra- } \\
\text { teegiad }\end{array}$ & $\begin{array}{c}\text { Metakog- } \\
\text { nitiivsed } \\
\text { stra- } \\
\text { teegiad }\end{array}$ & $\begin{array}{c}\text { Seos- } \\
\text { tamis- } \\
\text { stra- } \\
\text { teegiad }\end{array}$ & $\begin{array}{c}\text { Sotsiaal- } \\
\text { sed } \\
\text { stra- } \\
\text { teegiad }\end{array}$ & $\begin{array}{c}\text { Aktiivne } \\
\text { keele- } \\
\text { kasutus }\end{array}$ \\
\hline Otsene mõju & & 0,05 & & $-3,01$ & $-0,19$ & 3,54 \\
\hline Rääkimispädevus & $-0,01$ & & $-4,44$ & $-0,35$ & 5,02 \\
\hline Lugemispädevus & 0,03 & & $-4,72$ & $-0,31$ & 5,21 \\
\hline Kuulamispädevus & & 0,05 & & $-3,69$ & $-0,24$ & 4,16 \\
\hline Kirjutamispädevus & & & & & & \\
\hline Kaudne mõju & 0,47 & & $-0,23$ & & & \\
\hline Rääkimispädevus & 0,50 & & $-0,38$ & & & \\
\hline Lugemispädevus & 0,42 & & $-0,39$ & & & \\
\hline Kuulamispädevus & 0,41 & & $-0,30$ & & & \\
\hline Kirjutamispädevus & 0,40 & & & & \\
\hline
\end{tabular}

Kaudne mõju õpitulemustele avaldus metakognitiivsete ja kompensatsioonistrateegiate kasutamisel. Kui metakognitiivsete strateegiate mõju oli negatiivne kõigi pädevuste korral, siis kompensatsioonistrateegiate mõju oli positiivne. 
Tabel 6. Metakognitiivsete ja kompensatsioonistrateegiate standardiseeritud otsene mõju

\begin{tabular}{|c|c|c|c|c|c|c|}
\hline & $\begin{array}{l}\text { Kompen- } \\
\text { satsiooni- } \\
\text { stra- } \\
\text { teegiad }\end{array}$ & $\begin{array}{l}\text { Mälu- } \\
\text { stra- } \\
\text { teegiad }\end{array}$ & $\begin{array}{l}\text { Metakog- } \\
\text { nitiivsed } \\
\text { stra- } \\
\text { teegiad }\end{array}$ & $\begin{array}{l}\text { Seos- } \\
\text { tamis- } \\
\text { stra- } \\
\text { teegiad }\end{array}$ & $\begin{array}{l}\text { Sotsiaal- } \\
\text { sed } \\
\text { stra- } \\
\text { teegiad }\end{array}$ & $\begin{array}{l}\text { Aktiivne } \\
\text { keele- } \\
\text { kasutus }\end{array}$ \\
\hline \multicolumn{7}{|l|}{ Otsene mõju } \\
\hline Aktiivne keelekasutus & 0,94 & & 0,07 & & & \\
\hline Sotsiaalsed strateegiad & 0,26 & & 0,44 & & & \\
\hline Seostamisstrateegiad & 0,94 & & 0,13 & & & \\
\hline
\end{tabular}

Et mõista, mida metakognitiivsete ja kompensatsioonistrateegiate kaudne mõju õpitulemustele tegelikult tähendab, vaadati lähemalt, milline on nende strateegiate mõju teistele strateegiarühmadele. Ilmnes, et kompensatsioonistrateegiad avaldavad aktiivse keelekasutuse ja seostamisstrateegiatele otsest positiivset mõju, kuid mõju sotsiaalsetele strateegiatele on pisut väiksem (tabel 6). Metakognitiivsetel strateegiatel on positiivne mõju nii aktiivse keelekasutuse, sotsiaalsetele kui ka seostamisstrateegiatele, kuid neist kahe esimese puhul on mõju äärmiselt väike.

\section{Arutelu}

Uurimuse eesmärk oli kontrollida eri keeleõppestrateegiate taksonoomiate kehtivust empiiriliste andmete põhjal ning analüüsida kasutatavate keeleõppestrateegiate ja õpitulemuste vahelist võimalikku seost abiturientidest koosneva valimi peal. Uurimistulemused näitasid, et valimisse kuulunud abiturientide strateegiakasutuse kohta kogutud andmed peegeldasid sellist struktuuri, millel on kokkulangevusi nii Oxfordi (1990), Coheni (2014) kui ka O’Malley ja Chamoti (2002) õpistrateegiate taksonoomiatega. Loodud mudelisse jäi algse 50 väite asemel 17. Mudel sisaldab kuut faktorit, millest neli - metakognitsioon, sotsiaalsed, kompensatsiooni- ja mälustrateegiad langesid kokku SILLi originaalmudeliga (Oxford, 1990). Nendele lisaks tekkis kaks uut strateegiarühma: aktiivne keelekasutus ja seostamisstrateegiad. Aktiivse keelekasutuse strateegiad väljendavad õppija algatatud tegevusi keele kasutamisel reaalelulistes või sellele lähedastes olukordades. See rühm moodustus SILLi kognitiivsetest ja sotsiaalsetest strateegiatest ning kattub suuresti Coheni (2014, lk 13-14) harjutamise ja kommunikatiivsete strateegiatega. Sotsiaalsete strateegiate rühmal on suur kokkulangevus O’Malley ja Chamoti (2002, lk 199) sotsiaal-afektiivsete strateegiate 
rühma kuuluvate täpsustavate ja selgitavate küsimuste esitamise strateegiatega. Kuigi nime poolest on tegemist sotsiaalsete strateegiatega, siis sisult on need abi otsimise ja küsimise strateegiad. Ka Est-SILLis moodustunud seostamisstrateegiate rühmal on rohkem ühist O’Malley ja Chamoti (ibid.) kognitiivsete strateegiate rühma kuuluvate täpsustamise ja ülekandmise strateegiatega kui SILLi mälustrateegiatega, kust need on pärit. Samamoodi nagu praeguses uuringus saadud lahendi korral, leiab aktiivse keelekasutuse strateegiarühma ka teistest SILLi valiidsusuuringutest, mis on tehtud näiteks Puerto Ricos (Green \& Oxford, 1993, viidatud Oxford \& BurryStock, 1995 järgi), Taiwanis (Yang, 1992, viidatud Oxford \& Burry-Stock, 1995 järgi), Hiinas (Zhang, 1994, viidatud Oxford \& Burry-Stock, 1995 järgi), Jaapanis (Watanabe, 1991), Egiptuses (Boraie, Kassabgy, \& Oxford, 1994) ja Ameerika Ühendriikides (Anderson, 1993, viidatud Oxford \& Burry-Stock, 1995 järgi). Seostamisstrateegiate sarnaseid strateegiarühmi pole aga seni avaldatud uurimistulemustes välja toodud.

Järgnevalt analüüsiti õppijate keeleõppestrateegiate kasutust seoses kaks kuud pärast strateegiate küsimustiku täitmist tehtud inglise keele riigieksami tulemustega. Et leida seoseid tajutava strateegiakasutuse ja õpiedu vahel, loodi kolm mudelit - ühetasandiline, hierarhiline ja vahendatud mudel -, mida kontrolliti struktuurivõrrandite meetodil. Mudeli headuse näitajate põhjal osutus neist kolmest parimaks vahendatud mudel. Selle mudeli ülesehitus põhines teooriast saadud teadmistel kognitiivsete ja metakognitiivsete õpistrateegiate seostest ja vastastikusest mõjust (Phakiti, 2003; Purpura, 1997; Zhang, 2010). Kuna korrelatsioonikordajad ei näidanud statistiliselt olulisi seoseid metakognitiivsete ja kompensatsioonistrateegiate ning õpitulemuste vahel, siis oli oluline uurida strateegiate otsest ja kaudset mõju nii õpitulemustele kui ka teistele strateegiarühmadele.

Nii nagu Purpura (1997) ja Zhangi (2014) uuringust, selgus ka praegusel juhul, et kognitiivsed õpistrateegiad (aktiivne keelekasutus ja seostamisstrateegiad) panustavad otseselt ópitulemustesse. Sealjuures oli aktiivse keelekasutuse mõju õpipädevusele suur, mistõttu võib öelda, et eelkõige just nende strateegiate kasutuse toetamine näib tagavat parima õpiedu. Kui aktiivse keelekasutuse mõju õpiedule oli positiivne, siis seostamisstrateegiate mõju oli negatiivne. See tähendab, et seostamisstrateegiate kasutamine õpiprotsessis võib anda hiljem halvema tulemuse riigieksamil. Seostamisstrateegiate oskuslikku kasutamist peetakse aga oluliseks varem õpitu ja uue materjali seostamisel ning seda eelkõige õpiprotsessis (Pintrich, 2004; O’Malley \& Chamot, 2002, lk 199). Praegused uurimistulemused tõstatavad seega küsimuse inglise keele riigieksami ülesannete edukaks sooritamiseks eeldatavatest õpioskustest. Otsest negatiivset mõju 
õpiedule leiti ka sotsiaalsete õpistrateegiate kasutamisel, kuid nende mõju oli mõnevõrra väiksem. Est-SILLi kaasatud sotsiaalsed õpistrateegiad on suunatud eelkõige abi otsimisele ning kaaslaste abi kasutamisele, nende strateegiate rakendamine ópiolukorras ei pruugi toetada edu saavutamist testi ajal. Kuigi teooria põhjal on näidatud, et metakognitiivsed õpioskused on olulised hea keeleoskuse saavutamiseks (Benson, 2011, lk 97-98; O’Malley \& Chamot, 2002, lk 47-49; Phakiti, 2003), on mõnest uuringust ilmnenud, et metakognitiivsed strateegiad ei panusta õpitulemustesse otseselt, vaid kaudselt, st kognitiivsete strateegiate kaudu (nt Purpura, 1997).

Kuna praegusest uuringust ilmnenud korrelatsioonikordajad lubasid eeldada kaudset mõju ka kompensatsioonistrateegiate korral, siis uuriti lähemalt, kuidas need kaks strateegiarühma käituvad õpitulemuste ja teiste strateegiarühmade suhtes. Kompensatsioonistrateegiad avaldavad õpiedule positiivset kaudset mõju. Metakognitsiooni kaudne mõju õpiedule on aga negatiivne. Et mõista paremini kaudset mõju ja vahendavaid strateegiarühmi, keskenduti uuringus metakognitiivsete ja kompensatsioonistrateegiate otsese mõju uurimisele. Mõlemal strateegiarühmal ilmneski positiivne mõju kognitiivsetele strateegiatele, ometi oli osal juhul mõju väga nõrk. Metakognitiivsetel strateegiatel oli arvestatav positiivne mõju sotsiaalsete strateegiate kasutamisele, kompensatsioonistrateegiatel oli aga positiivne mõju nii aktiivsele keelekasutusele kui ka seostamisstrateegiatele. See tähendab, et õppija oskuslik metakognitiivne tegevus, eelkõige oma tegevuse jälgimine ja hindamine, võimaldab tal edukamalt rakendada sotsiaalseid strateegiaid juhul, kui soovitakse hinnata kaaslastelt abi küsimise vajalikkust ja nende abi kasutada. Kompensatsioonistrateegiate teadlik kasutamine toetab aga õppija aktiivset keelekasutust, seda nii suulises kui ka kirjalikus suhtluses, ja seostamisoskuse rakendamist ning selle kaudu ka positiivse õpitulemuse saavutamist. Seega saab väita, et metakognitiivsed strateegiad, mida peetakse üldiselt oluliseks õpiprotsessis ja õppija arengu toetamisel, ei näi avaldavat otsest mõju positiivsele testitulemusele inglise keele riigieksamil. Pigem võimaldavad tulemused väita, et metakognitiivsete õpistrateegiate kasutamise oskus toetab õppijate kognitiivsete ja sotsiaalsete strateegiate oskuslikumat kasutamist ópiprotsessis ning see omakorda võiks avaldada positiivset mõju riigieksami tulemustele.

Eelkirjeldatud uurimistulemused olid autorite jaoks mõneti üllatavad, sest PISA tulemuste eeskujul (vt nt Mikk, Kitsing, Must, Säälik, \& Täht, 2012) eeldati metakognitiivsete õpistrateegiate suuremat mõju õpitulemustele. Kuigi inglise keele riigieksami tulemused on olnud aastate jooksul suhteliselt kõrgel tasemel - 2011 - 72,0; 2012 - 68,6; 2013 - 72,0; 2014 67,5 (2014. aasta ..., 2014) -, ei paista need olevat seotud metakognitiivsete 
strateegiate kasutamisega õpiprotsessis. Kuna praegune uuring ei paku ühest selgitust, siis võib arutleda, kas võõrkeele omandamise edukust mõjutavadki peamiselt vaid aktiivse keelekasutuse strateegiad või on riigieksami ülesanded koostatud selliselt, et mõõdetakse spetsiifilisi teadmisi ja oskusi, mille omandamiseks ei ole tingimata vaja metakognitiivseid õpistrateegiaid. Et saada paremat ettekujutust õpitulemuste kujunemisest ja seotusest õpiprotsessis kasutatavate strateegiatega, oleks oluline uurida selles kontekstis ka riigieksamiteks valmistumise protsessi ning keeleõppijate testitegemise strateegiaid.

Kokkuvõtteks võib öelda, et kõnealune uuring andis panuse võõrkeeleõppe uuringutesse kahel moel. Esiteks on nüüd võimalik Eestis kasutada valiidset eestikeelset enesekohast küsimustikku Est-SILL võõrkeeleõppijate õpistrateegiate mõõtmiseks. Küsimustiku struktuur, mis erineb küll mõneti SILLi originaalstruktuurist, peegeldab õpistrateegiate mitmemõõtmelisust ja omavahelist seotust. Samas andis uuring kinnitust keeleõppestrateegiate klassifitseerimise keerukusest. Nii nagu paljudes rahvusvahelistes uuringutes, eristus ka praeguses klassifikatsioonis aktiivse keelekasutuse strateegiarühm, mis osutus tugevaimaks õpitulemuste ennustajaks. Teiseks andis uuring tunnistust õpistrateegiate rollist õpitulemuste kujunemisel. Uuring kinnitas, et kognitiivsetel õpistrateegiatel on otsene mõju õpiedule kõigi nelja keelepädevuse korral, kuid metakognitiivsete õpistrateegiate mõju on kaudne ning vajab koos õpiprotsessi ja testitegemise strateegiatega põhjalikumat uurimist, et mõista nende rolli õpitulemuste kujunemisel. Uurimistulemusi saab rakendada võõrkeeleõppes ja õpetajakoolituses, suunates õppijate ja õpetajate tähelepanu tõhusaimate keeleõppestrateegiate õpetamisele eesmärgiga saavutada paremad õpitulemused.

\section{Tänuavaldus}

Artikli valmimist toetas Euroopa sotsiaalfond haridus- ja kasvatusteaduste doktorikooli kaudu (1.2.0401.09-0070).

\section{Kasutatud kirjandus}

2014. aasta inglise keele riigieksami lühianalüüs (2014). Innove. Külastatud aadressil http://www.innove.ee/UserFiles/Riigieksamid/2014/Statistika/2014.\%20a.\%20 inglise\%20keele\%20riigieksami\%20anal\%C3\%BC\%C3\%BCs.pdf.

Bachman, L. F., \& Palmer, A. S. (2010). Language testing in practice. Oxford, UK: Oxford University Press. 
Benson, P. (2011). Teaching and researching autonomy (2nd ed.). Harlow: Pearson Education.

Boraie, D., Kassabgy, O., \& Oxford, R. (1994). Empowering teachers and learners: Style and strategy awareness. Paper presented at the annual meeting of Teachers of English to Speakers of Other Languages, Baltimore, Maryland.

Brown, T. A. (2006). Confirmatory factor analysis for applied research. New York, London: The Guilford Press.

Brown, A. L., Bransford, J. D., Ferrara, R. A., \& Campione, J. C. (1983). Learning, remembering, and understanding. In J. H. Flavell \& M. Markman (Eds.), Carmichael's manual of child psychology (Vol. 3, pp. 77-166). New York: Wiley.

Brown, A. L., \& Palincsar, A. S. (1982). Inducing strategies learning from texts by means of informed, self-control training. Topics in Learning and Learning Disabilities, 2(1), 1-17.

Chamot, A. M., Kupper, L., \& Impink-Hernandez, M. (1988). A study of learning strategies in foreign language instruction: Findings of the longitudinal study. McLean, VA: Interstate Research Associates.

Cohen, A. D. (1996). Second language learning and use strategies: Clarifying the issues. Research report (rev. ed.) Corporate Source: Minnesota University, Minneapolis. Center for Advanced Research on Language Acquisition.

Cohen, A. D. (2006). The coming of age of research on test-taking strategies. Language Assessment Quarterly, 3(4), 307-331.

doi: http://dx.doi.org/10.1080/15434300701333129

Cohen, A. D. (2014). Strategies in learning and using a second language (2nd ed.) London, New York: Routledge.

Dansereau, D. F. (1985). Learning strategy research. In J. W. Segal, S. F. Chipman, \& R. Glaser (Eds.), Thinking and learning skills: Relating learning to basic research (pp. 209-240). Hillsdale, NJ: Erlbaum.

Euroopa Nõukogu (2007). Euroopa keeleõppe raamdokument. Külastatud aadressil http://www.hm.ee/index.php?popup=download\&id=5700.

Flavell, J. H. (1979). Metacognition and cognitive monitoring: A new area of cognitive-developmental inquiry. American Psychologist, 34(10), 906-911. doi: http://dx.doi.org/10.1037/0003-066X.34.10.906

Green, J., \& Oxford, R. (1995). A closer look at learning strategies, L2 proficiency, and gender. TESOL Quarterly, 29(2), 261-297.

doi: http://dx.doi.org/10.2307/3587625

Guillemin, F., Bombardier, C., \& Beaton, D. (1993). Cross-cultural adaptation of health-related quality of life measures: Literature review and proposed guidelines. Journal of Clinical Epidemiology, 46(12), 1417-1432. doi: http://dx.doi.org/10.1016/0895-4356(93)90142-N

Hsiao, T.-Y., \& Oxford, R. L. (2002). Comparing theories of language learning strategies: A confirmatory factor analysis. The Modern Language Journal, 86(3), 368383. doi: http://dx.doi.org/10.1111/1540-4781.00155

Hu, L., \& Bentler, P. M. (1999). Cutoff criteria for fit indexes in covariance structure analysis: Conventional criteria versus new alternatives. Structural Equation Modeling, 6(1), 1-55. doi: http://dx.doi.org/10.1080/10705519909540118 
Inglise keele riigieksami eristuskiri 2014 (2014). Innove. Külastatud aadressil http://www.innove.ee/UserFiles/Riigieksamid/Inglise\%20keel\%202014/RE\%20 inglise\%20keel\%20eristuskiri\%202014(2).pdf.

Johnson, R., \& Rao, V. (2010). Standardized tests. In T. C. Hunt, J. C. Carper, T. J. Lasley, \& C. D. Raisch (Eds.), Encyclopedia of educational reform and dissent. SAGE Publications.

Kauffman, D. F., Zhao, R., \& Yang, Y.-S. (2011). Effects of online note taking formats and self-monitoring prompts on learning from online text: Using technology to enhance self-regulated learning. Contemporary Educational Technology, 36(4), 313-322. doi: http://dx.doi.org/10.1016/j.cedpsych.2011.04.001

Kramarski, B., \& Michalsky, T. (2010). Preparing preservice teachers for self-regulated learning in the context of technological pedagogical content knowledge. Learning and Instruction, 20(5), 434-447. doi: http://dx.doi.org/10.1016/j.learninstruc.2009.05.003

Mikk, J., Kitsing, M., Must, O., Säälik, Ü., \& Täht, K. (2012). Eesti PISA 2009 kontekstis: tugevused ja probleemid. Programmi Eduko uuringutoetuse kasutamise lepingu aruanne. Tartu.

Nunnally, J., \& Bernstein, L. (1994). Psychometric theory (3rd ed.). New York: McGraw-Hill Higher.

O'Malley, J. M., \& Chamot, A. U. (2002). Learning strategies in second language acquisition. Cambridge: Cambridge University Press.

Oxford, R. L. (1990). Language learning strategies: What every teacher should know. New York: Newbury House/Harper and Row.

Oxford, R. L., \& Burry-Stock, J. A. (1995). Assessing the use of language learning strategies worldwide with the ESL/EFL version of the Strategy Inventory of Language Learning (SILL). System, 23(1), 1-23. doi: http://dx.doi.org/10.1016/0346-251X(94)00047-A

Park, G.-P. (2011). The validation process of the SILL: A confirmatory factor analysis. English Language Teaching, 4(4), 21-27. doi: http://dx.doi.org/10.5539/elt.v4n4p21

Phakiti, A. (2003). A closer look at the relationship of cognitive and metacognitive strategy use to EFL reading achievement test performance. Language Testing, 20(1), 26-56. doi: http://dx.doi.org/10.1191/0265532203lt243oa

Pintrich, P. (2004). A conceptual framework for assessing motivation and selfregulated learning in college students. Educational Psychology Review, 16(4), 385-407. doi: http://dx.doi.org/10.1007/s10648-004-0006-x

Purpura, J. E. (1997). An analysis of the relationships between test takers' cognitive and metacognitive strategy use and second language test performance. Language Learning, 47(2), 289-325. doi: http://dx.doi.org/10.1111/0023-8333.91997009

Purpura, J. E. (1998). Investigating the effects of strategy use and second language test performance with high- and low-ability test takers: A structural equation modelling approach. Language Testing, 15(3), 333-379.

doi: http://dx.doi.org/10.1177/026553229801500303

Rigney, J. W. (1978). Learning strategies: A theoretical perspective. In H. F. O'Neil, Jr. (Ed.), Learning strategies (pp. 165-205). New York: Academic Press. 
Rose, H. (2012). Language learning strategy research: Where do we go from here? Studies in Self-Access Learning Journal, 3(2), 137-148.

Rubin, J. (1975). What the "good language learner” can teach us. TESOL Quarterly, 9(1), 41-51. doi: http://dx.doi.org/10.2307/3586011

Saks, K., \& Leijen, Ä. (2015). Kognitiivsete ja metakognitiivsete õpistrateegiate toetamine tehnoloogiaga tõhustatud keeleõppes. Eesti Haridusteaduste Ajakiri, 3(2), 130-155. doi: http://dx.doi.org/10.12697/eha.2015.3.2.05

Saks, K., Leijen, Ä., Õun, K., \& Täht, K. (2015). Factorial structure of SILL revisited: Adaptation of SILL for Estonian EFL learners. Eesti Rakenduslingvistika Ühingu aastaraamat, 11, 241-261. doi: http://dx.doi.org/10.5128/ERYa11.15

Zhang, L. J. (2010). A dynamic metacognitive systems account of Chinese university students' knowledge about EFL reading. TESOL Quarterly, 44(2), 320-353. doi: http://dx.doi.org/10.5054/tq.2010.223352

Zhang, L., Goh, C. C. M., \& Kunnan, A. J. (2014). Analysis of test takers' metacognitive and cognitive strategy use and EFL reading test performance: A multisample SEM approach. Language Assessment Quarterly, 11(1), 76-102. doi: http://dx.doi.org/10.1080/15434303.2013.853770

Tasemetööde ning põhikooli ja gümnaasiumi lõpueksamite ettevalmistamise, koostamise, läbiviimise ja hindamise tingimused ja kord ning tasemetööde, ühtsete põhikooli lõpueksamite ja riigieksamite tulemuste analüüsimise tingimused ja kord (2010). Riigi Teataja I 2010, 67, 502. Külastatud aadressil https://www.riigiteataja.ee/akt/13359329.

Tragant, E., Thomson, M. S., \& Victori, M. (2013). Understanding foreign language learning strategies: A validation study. System, 41(1), 95-108. doi: http://dx.doi.org/10.1016/j.system.2013.01.007

Watanabe, Y. (1991). Classification of language learning strategies. International Christian University Language Research Bulletin, 6(1), 75-102.

Wesche, M. B. (1987). Second language performance testing: The Ontario Test of ESL as an example. Language Testing, 4(1), 28-47. doi: http://dx.doi.org/10.1177/026553228700400103

Wong, M. S.-L. (2011). Language learning strategy use: A study of pre-service teachers in Malaysia. Malaysia: Teacher Education Institute. Retrieved from http://www.eric.ed.gov/PDFS/ED521415.pdf.

Woodrow, L. (2005). The challenge of measuring language learning strategies. Foreign Language Annals, 38(1), 90-98.

doi: http://dx.doi.org/10.1111/j.1944-9720.2005.tb02456.x 
Lisa 1. Keeleõppestrateegiate loend Est-SILL

Käesolev eesti õppijate jaoks kohandatud keeleõppestrateegiate loend (Est-SILL) on loodud mõõtmaks võõrkeele õppijate keeleõppestrateegiaid. Loe läbi iga väide, meenuta, kuidas Sa õpid/õppisid inglise vm võõrkeelt, ja tee ring sobiva vastusevariandi ümber vastavalt sellele, KUI ÕIGE SEE VÄIDE SINU PUHUL ON.

1 Mitte kunagi või peaaegu mitte kunagi õige

2 Tavaliselt ei ole õige

3 Mõneti õige

4 Tavaliselt õige

5 Alati või peaaegu alati õige

Vali vastusevariant vastavalt sellele, kui hästi see väide peab Sinu puhul paika. Ära vasta selle põhjal, kuidas Sa arvad, et võiks olla või mida teised inimesed teevad. Neile väidetele pole õigeid ega valesid vastuseid.

\begin{tabular}{|c|l|c|c|c|c|c|}
\hline & \multicolumn{5}{|c|}{ Punktid } \\
\hline 1 & Ma esitan küsimusi võõrkeeles. & 1 & 2 & 3 & 4 & 5 \\
\hline 2 & Ma alustan vestlust võõrkeeles. & 1 & 2 & 3 & 4 & 5 \\
\hline 3 & $\begin{array}{l}\text { Ma püüan leida võimalikult palju võimalusi võõrkeele } \\
\text { kasutamiseks. }\end{array}$ & 1 & 2 & 3 & 4 & 5 \\
\hline 4 & $\begin{array}{l}\text { Ma püüan rääkida nagu seda võõrkeelt emakeelena } \\
\text { kõneleja. }\end{array}$ & 1 & 2 & 3 & 4 & 5 \\
\hline 5 & Ma mõtlen oma võõrkeeleõpingute edenemise peale. & 1 & 2 & 3 & 4 & 5 \\
\hline 6 & $\begin{array}{l}\text { Ma planeerin oma tegevust, et mul oleks piisavalt aega } \\
\text { võõrkeelt õppida. }\end{array}$ & 1 & 2 & 3 & 4 & 5 \\
\hline 7 & Ma püüan saada paremaks võõrkeele õppijaks. & 1 & 2 & 3 & 4 & 5 \\
\hline 8 & $\begin{array}{l}\text { Mul on selged eesmärgid oma võõrkeeleoskuse } \\
\text { parandamiseks. }\end{array}$ & 1 & 2 & 3 & 4 & 5 \\
\hline 9 & $\begin{array}{l}\text { Kui ma ei saa millestki võõrkeeles aru, siis ma palun } \\
\text { inimesel rääkida aeglasemalt või palun tal seda korrata. }\end{array}$ & 1 & 2 & 3 & 4 & 5 \\
\hline 10 & Ma palun vajadusel võõrkeeles kõnelevalt inimeselt abi. & 1 & 2 & 3 & 4 & 5 \\
\hline 11 & $\begin{array}{l}\text { Ma palun võõrkeeles kõneleval inimesel end } \\
\text { parandada, kui ma teen vigu. }\end{array}$ & 1 & 2 & 3 & 4 & 5 \\
\hline 12 & $\begin{array}{l}\text { Mõistmaks uusi võõrkeelseid sõnu, püüan ma } \\
\text { tähendust ära arvata. }\end{array}$ & 1 & 2 & 3 & 4 & 5 \\
\hline 13 & $\begin{array}{l}\text { Kui mul ei tule vestluse ajal vajalik sõna meelde, } \\
\text { kasutan ma žeste. }\end{array}$ & 1 & 2 & 3 & 4 & 5 \\
\hline 14 & $\begin{array}{l}\text { Ma kasutan uute võõrkeelsete sõnade meeldejätmiseks } \\
\text { sõnakaarte. }\end{array}$ & 1 & 2 & 3 & 4 & 5 \\
\hline 15 & Ma kasutan võõrkeelsete sõnade meeldejätmiseks liigutusi. & 1 & 2 & 3 & 4 & 5 \\
\hline 16 & $\begin{array}{l}\text { Ma kasutan lauses uusi võõrkeelseid sõnu, et neid } \\
\text { paremini meelde jätta. }\end{array}$ & 1 & 3 & 4 & 5 \\
\hline 17 & Ma mõtlen varem õpitu ja uute asjade vahelistele seostele. & 1 & 2 & 3 & 4 & 5 \\
\hline
\end{tabular}


Lisa 2. Est-SILLi mudel (kinnitav faktoranalüüs, AMOS)

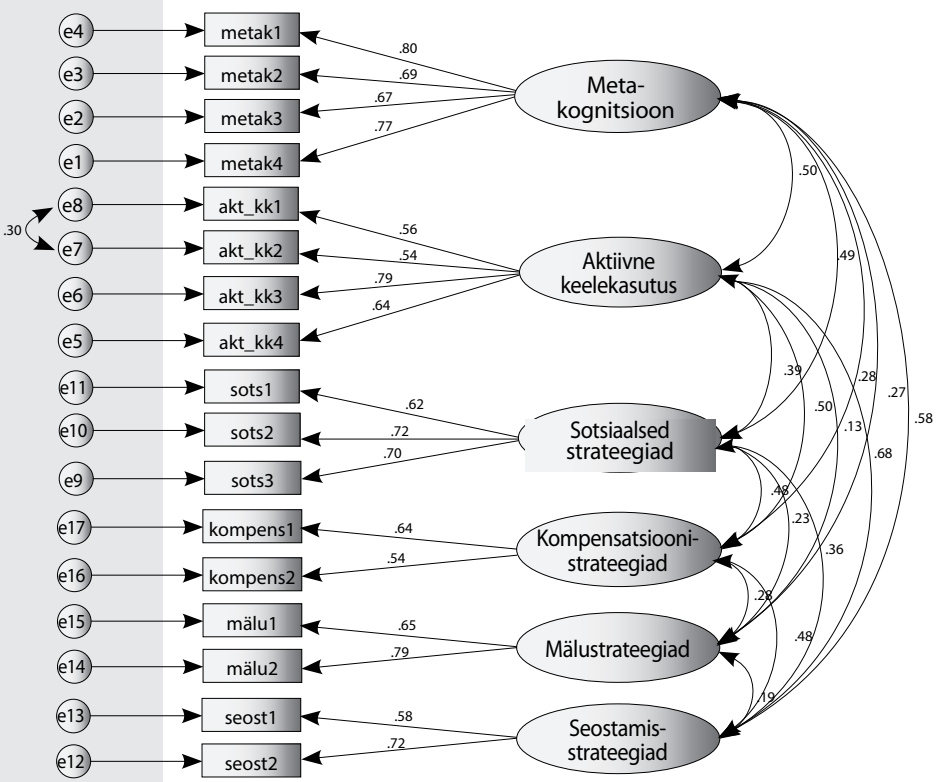




\title{
Language learning strategies of EFL learners and their effects on learning outcomes
}

\author{
Katrin Saks ${ }^{\mathrm{a}}$, Äli Leijen ${ }^{\mathrm{a}}$, Karin Täht ${ }^{\mathrm{b}}$ \\ ${ }^{a}$ Institute of Education, University of Tartu \\ ${ }^{b}$ Institute of Psychology, University of Tartu
}

\section{Summary}

\section{Introduction}

The aim of the current research was to validate the classification of language learning strategies (LLS) that suits best the empirical data collected within the study, and to investigate the relations of LLS and their effects on learning outcomes.

Learning strategies are activities taken by the learner to aid the acquisition, storage, retrieval, and use of information (Oxford, 1990). The correlation between learning strategies and learning outcomes enables them the assessment of the efficiency of strategy use (Hsiao \& Oxford, 2002; O'Malley \& Chamot, 1990; Rubin, 1975). Language learning strategies have been classified in different ways. Oxford divided them into six categories: memory, cognition, compensation, metacognitive, affective and social strategies. Although she distinguished cognitive, memory and compensation strategies, they overlap in their content. Other researchers have observed memory strategies as cognitive ones (e.g. O’Malley \& Chamot, 2002; Phakiti, 2003; Purpura, 1997). Even though Oxford's taxonomy is most widely accepted, and SILL is the most widely used instrument to assess LLS, many researchers have questioned its reliability as there is no solid evidence of its six-factor structure (Park, 2011; Rose, 2012; Saks et al., 2015; Woodrow, 2005).

Other scholars have suggested different classifications of LLS. Cohen (1996) distinguished two subdivisions: language learning strategies and language use strategies. Another way of classifying LLS is according to function. O'Malley and Chamot (2002, pp. 44-46) presented three main strategy groups - cognitive, metacognitive and socio-affective strategies. Based on cognitive theory, the content of their subdivisions is quite similar to the ones of SILL. However, in their division O'Malley and Chamot go deeper and distinguish the strategies in a more detailed manner.

1 Institute of Education, University of Tartu, Salme 1a, 50103 Tartu, Estonia; katrin.saks@ut.ee 
Although LLS has been extensively investigated, there is no solid understanding as to whether and how the learner's LLS are connected with his proficiency and whether and how the test results reflect his strategy use. The efficiency of language studies is predominantly assessed with language tests. The English state exam that Estonian school-leavers have to write is a standardised test. It consists of four parts and measures students' listening, writing, speaking and reading competencies.

The aim of the present study was to create a model that described the taxonomy of LLS (Est-SILL). To investigate the relations between strategies and outcomes, three structural equation models were created and their effects on outcomes were assessed. Proceeding from the aim of the study the following research questions were posed:

1. Which is the factor structure of the questionnaire of LLS translated and adapted for Estonian EFL learners?

2. How are the LLS connected with the learning outcomes in four competencies?

\section{Methodology}

The sample for the study consisted of 383 final-grade students from all gymnasiums in Pärnu. 269 of them (71\%) were present at school on the day the questionnaire was answered. The average age of the respondents was $18.4(S D=.5), 55 \%$ were girls and $45 \%$ were boys. By the time of the study they had been studying English for approximately 10 years $(M=10.22$; $S D=1.3)$.

During the data collection, respondents were asked to assess the statements of SILL on a scale from 1-5. It was explained to the students that with their written consent, the data collected with the questionnaire would be analysed along with the results of their English state examination that they would have had to take 2 months later.

In order to answer the first research question the exploratory factor analysis was conducted. The solution was tested with confirmatory factor analysis (CMIN/DF, CFI, RMSEA).

To answer the second research question on the relations of learner's LLS and learning outcomes three different structural equation models were created and tested. The analyses were performed with the software programs SPSS 20 and AMOS. 


\section{Results and conclusions}

The aim of the current study was to check the validity of different taxonomies of LLS, and analyse the relations between the use of LLS and learning outcomes.

The solution of the EFA was a six factor structure. Factor loadings greater than, or equal to, 0.5 accounted for over $68 \%$ of the variance. The new scale of Est-SILL had 17 statements instead of 50 original ones. The factors were active language use, metacognition, social, compensation, memory and connecting strategies. The validity of the model of Est-SILL was tested with a CFA. The model fit indices were good: $\chi^{2}=201,405 ; d f=103$; $\mathrm{CMIN} / \mathrm{DF}=1.96 ; \mathrm{CFI}=0.92 ; \mathrm{RMSEA}=0.06$. The model of Est-SILL included six factors, four of them - metacognition, social, compensation and memory strategies - coincided with the original model of SILL (Oxford, 1990). In addition, two new strategy groups were formed - active language use and connecting strategies. The strategies of active language use expressing the learner initiated activities used in real life situations was formed of cognitive and social strategies and considerably overlapped with Cohen's (1996) rehearsal and communication strategies. The group of social strategies of Est-SILL had overlapping with O'Malley and Chamot's (2002) strategies of questioning for clarification. The connecting strategies of Est-SILL have a lot in common with O'Malley and Chamot's (ibid.) elaboration and transfer strategies. The structure of Est-SILL and the large-scale concurrence with different taxonomies reveal the complicacy of structuring LLS because of interpreting and specifying their content and major overlapping.

The relations between learners' strategy use and their learning outcomes were investigated with a SEM analysis which revealed good results on unitary and mediated models. Drawn on the fit indices and correlation coefficients between LLS and learning outcomes, we proceeded with the mediated model. As correlation co-efficients did not show any significant relations between metacognitive and compensation strategies, and learning outcomes, it became important to investigate the direct and indirect effects of LLS on learning outcomes and other strategy groups.

Similarly to Purpura (1997) and Zhang (2014), the results of the current study revealed that cognitive learning strategies (active language use and connecting strategies) are directly connected with the learning outcomes. While the effect of active language use on the outcome was positive, the effect of connecting strategies was negative. It means that using connecting strategies in the tense test situation may lead to lower test results throughout all four competencies. The direct negative effect on learning outcomes 
was also detected in the case of social strategies. The current study showed that metacognitive strategies do not contribute to the learning outcomes directly but indirectly through cognitive strategies (e.g. Purpura, 1997). Metacognitive as well as compensation strategies revealed a positive effect on cognitive strategies, however, some of these were very weak. Metacognitive strategies had a significantly positive effect on the use of social strategies. Compensation strategies had a positive effect on active language use and connecting strategies. It can be stated that metacognitive strategies that are important in the learning process, do not reveal considerable significance in the test results. Metacognitive strategies should rather be instructed to enable learners the implementation of cognitive and social strategies more efficiently.

In conclusion, it can be said that the current study contributed to language learning in two ways. First, it provided a valid self-report questionnaire Est-SILL to measure the learners' LLS in the Estonian language. Its structure that differs a little from the original structure of SILL, reflects the multidimensional nature and associations of LLS. At the same time, the study confirmed the complicacy of classifying LLS. Similarly to many international studies, the strategy group of active language use distinguished among other strategies. The active language use strategies proved to be the strongest predictor of learning outcomes. Second, the study revealed the role of LLS in learning outcomes. The study confirmed the direct effect of cognitive strategies on all four language competences but the effect of metacognitive strategies is indirect and needs further research with the learning process and test-taking strategies. These results confirmed the findings of earlier studies which led us to conclude that the effect of learning strategies on outcomes does not depend on the learning context, but are transferrable to other foreign language learning contexts. The results of the research can be implemented in language studies and teacher training directing learners' and teachers' attention to teaching the most efficient LLS to achieve better results.

Keywords: language learning strategies, structural equation model, confirmatory factor analysis 